\title{
TRADISI BER-HAJI DI GANTARANG DAN BERKAH TANADOANG KEPULAUAN SELAYAR
}

\section{Syakinah}

Universitas Negeri Makasar, Indonesia

Email: syakinah.1968041028@gmail.com

\begin{tabular}{ll}
\hline INFO ARTIKEL & ABSTRAK \\
\hline Diterima & Penduduk selayar masih banyak yang percaya pada dunia ghaib,roh-roh \\
15 Desember 2021 & halus dan berbagai kekuatan sakti lainnya (religio-magis).meskipun \\
Direvisi & penduduk kabupaten selayar mayoritas menganut ajaran agama \\
23 Desember 2021 & islam,namun dalam pelaksanaan syariat sebagian besar masih diwarnai \\
Disetujui & oleh sisa-sisa pengaruh ajaran agama hindu. Ajaran Hindu yang lebih \\
3 Januari 2022 & awal berpengaruh di Indonesia, rupanya telah menyimpan sisa-sisa \\
\hline Kata Kunci: & kepercayaan yang masih dipegang teguh oleh sebagian besar masyarakat \\
Tradisi Ber-Haji; & Selayar. Realitas tersebut tercermin melalui kebiasaan membakar \\
Berkah Tanadong; & kemenyan (dupa), menyiapkan sesajen, bunga-bungaan terutama dalam \\
Kepulauan Selayar & pelaksanaan upacara keagamaan dan upacara daur hidup. Upacara \\
& tersebut terdiri atas upacara memulai penebangan hutan (membuka lahan \\
& baru), memulai penanaman padi, panen, membuat emping/hasil laut, \\
& menghindarkan diri dari wabah penyakit (songkabala), upacara meminta \\
& hujan dan lain-lain. Timbulnya kecenderungan untuk tetap \\
& mempertahankan nilai-nilai budaya (tradisi) tersebut hingga eksis sampai \\
& sekarang pada prinsipnya disebabkan oleh lingkungan.menurut \\
& kepercayaan orang-orang yang meyakini tradisi "Ber-haji di gantarang \\
& dan Berkah Tanadoang",bahwa menunaikan sholat Idul Adha sebanyak 7 \\
& (tujuh) kali di Gantarang Lalang Bata,sama artinya atau kedudukannya \\
& dengan orang yang melakukan ibadah haji ke Tanah Suci Mekkah. \\
& Asumsi yang entah dalil apa yang dijadikan dasar ini, terbukti melalui \\
kecenderungan banyak orang yang berasal dari luar Gantarang & melakukan sholat Idul Adha di tempat ini.
\end{tabular}

\section{ABSTRACT}

Residents of Selayar still many who believe in the unseen world, spirits and various other powerful forces (religio-magis). although the residents of selayar district majority adhere to the teachings of Islam, but in the implementation of sharia is still mostly colored by the remnants of the influence of Hindu religious teachings. Early Hindu teachings are influential in Indonesia, apparently has kept the remnants of the belief that is still held firmly by most of the Selayar community. This reality is reflected through the habit of burning incense (incense), preparing offerings, flowers, especially in the implementation of religious ceremonies and life-cycle ceremonies. The ceremony consists of the ceremony of starting logging (opening new land), starting rice cultivation, harvesting, making emping / seafood, avoiding disease outbreaks (songkabala), ceremonies asking for rain and others. The emergence of the tendency to maintain cultural values (traditions) until it exists until now is in principle caused by the environment.according to the beliefs of people who believe in the tradition of "Hajj in gantarang

$\begin{array}{ll}\text { How to cite: } & \text { Syakinah (2022). Tradisi Ber-Haji Di Gantarang Dan Berkah Tanadoang Kepulauan Selayar, Action } \\ & \text { Research Literate, 6(1). } \\ \text { E-ISSN: } & 2721-2769 \\ \text { Published by: } & \text { Ridwan Institute }\end{array}$


Keywords:

Hajj Traditions; position as people who perform hajj to the Holy Land of Mecca. The

Blessings of assumption that somehow makes this basis, is proven through the

Tanadong; Selayar tendency of many people who come from outside Gantarang to perform Islands Eid al-Adha prayers in this place.

\section{Pendahuluan}

Tindakan memitos-sakralkan sesuatu termasuk mensucikan benda maupun tempat tertentu, secara sosio-kultural merupakan fenomena klasik yang masih terawat hingga era modern sekarang (A Ahmadin, 2008). Demikian penting dan berharganya nilai-nilai yang ada padanya, sehingga tidak jarang melahirkan kecenderungan yang mengarah pada fanatisme berlebihan. Bahkan tradisi yang terlanjur menjadi bagian integratif dari kehidupannya, kerap dianggap sebagai unsur pelengkap dari ajaran agama yang diyakini.

Berdasarkan keterangan beberapa orang Selayar yang pernah melakukan sholat Idul Adha di tempat ini, bahwa Gantarang dahulu mereka kunjungi setelah melakukan perjalanan yang cukup jauh, mereka harus melewati beberapa bukit dan tentu saja hutan rimba untuk sampai ke Gantarang Sungguh merupakan sebuah perjuangan yang tentu tidak mungkin dilakukan oleh seseorang, tanpa sebuah kekuatan motivatif luar biasa di balik semangat mereka (Widianingsih, 2021). Sebut saja baraka (berkah), itulah salah satu bahkan inti motivasi mereka sehingga demikian antusiasnya mengunjungi tempat penting ini. Jadi ibarat Tanah Suci Mekkah di Arab Saudi yang mereka sebut "Tanah Parallua", Gantarang Lalang Bata pun dipercayai sebagai "Tanah Parallu" (tanah yang penting) Bahkan tempat ini pun tidak jarang dinamakan sebagai miniatur Mekkah yang dalam bahasa setempat disebut Makka keke (Mekkah Kecil).

Penelitian ini dilakukan karena kepenasaran saya terhadap tradisi masyarakat selayar lebih tepatnya pada orang-orang yang berada pada daerah atau kampung yang bernama Gantarang Lalang Bata, adanya kegiatan yang dilaksanakan dengan cara yang berbeda pada setiap daerah. Selain itu saya ingin meneliti judul ini karena pada judul ini, tradisi yang saya angkat ialah salah satu tradisi masyarakat selayar yang masih ada dan masih dilaksanakan sampai sekarang ini meskipun tidak semua masyarakat melaksanakannya.

\section{Metode Penelitian}

Metode penelitian gunakan pada penelitian ini adalah metode penelitian kualitatif dengan pendekatan etnografi (Pratiwi, 2016). Berdasarkan jenis dan pendekatan penelitian ini, maka instrumen yang digunakan adalah human instrument, dalam hal ini peneliti berhubungan langsung dengan penelitian dan berperan sebagai pengumpul data, serta tidak dapat digantikan perannya. Teknik pengumpulan data dilakukan melalui observasi. Adapun prosedur penelitian yang dilakukan pada penelitian ini mengadopsi prosedur siklus penelitian etnografi oleh Spradley dalam Emzir (Wijaya, 2018) yang mencakup enam langkah.

Langkah pertama adalah pemilihan proyek etnografi. Siklus ini dimulai dengan memilih suatu proyek penelitan etnografi dengan mempertimbangkan ruang lingkup penelitian. Pendekatan etnografi merupakan pendekatan yang memperluas jangkauan sejauh masyarakat kebudayaan itu berkembang. Maka, etnografi mengamati seluruh aktifitas masyarakat yang diteliti. Etnografi menurut Spradley (Winarno, 2015) adalah penelitian untuk mendeskripsikan kebudayaan sebagaimana adanya. Metode etnografi Spradley bersumber dari satu aliran baru dalam ilmu antropologi yang disebut 
dengan antropologi kognitif, atau ethnoscience. Model ini berupaya mempelajari peristiwa kultural yang menyajikan pandangan hidup subjek sebagai objek studi. Studi ini akan terkait bagaimana subjek berpikir, hidup, dan berperilaku dalam menghadapi dunia sekeliling mereka. Dapat dikatakan bahwa pendekatan etnografi adalah kegiatan pengumpulan bahan keterangan atau data yang dilakukan secara sistematik mengenai cara hidup serta berbagai aktivitas sosial dan berbagai benda kebudayaan dari suatu masyarakat.

\section{Hasil dan Pembahasan}

Kata gantarang berasal dari kata GANG:jalan, TARANG:terang, LALANG:d alam dan BATA:pagar. Sehingga gantarang Lalang bata berarti sebuah daerah atau kampung yang dipagari oleh benteng menuju jalan yang terang. Kerajaan ini merupakan kerajaaan yang pertama kali menerima ajaran agama islam.

Dusun Gantarang Desa Bontomarannu Kecamatan Bontomanai. Gantarang saat ini dikenal sebagai perkampungan tua. Berada di atas ketinggian 275 meter dan dibatasi oleh lembah dibagian utara,selatan dan barat,serta laut disebelah timur. Bekas benteng kerajaan terbuat dari batu tersusun sampai kini masih dapat dilihat dan menjadi batas wilayah perkampungan tua gantarang. Daerah ini merupakan areal yang cenderung datar dan terletak pada puncak bukit karang dengan luas sekitar 4,6 hektar. Sekarang ini jumlah hunian sekitar kurang lebih 40 rumah dengan arah cenderung utara selatan. Tinggalan cagar budaya yang terdapat dikampung gantarang memperlihatkan eksistensi gantarang sebagai pemukiman tua dengan keadaan unsur budaya pendukungnya seperti benteng, masjid,lokasi ritual,pola tata ruang bangunan,kompleks makam,Meriam dan sebagainya (Ahmadin Ahmadin, 2011). Menurut cerita masyarakat,kerajaan gantarang memiliki empat pintu masuk, yaitu
1. Babaang Lembang-lembang,atau pintu barat berbatasan dengan jalan utama menuju kampung gantarang berukuran tinggi $200 \mathrm{~cm}$ dan lebar $60 \mathrm{~cm}$,konon pintu ini dijaga oleh seekor kerbau.

2. Babaang turungang atau pintu timur,berbatasan dengan teluk turungang dengan tinggi $135 \mathrm{~cm}$ dan lebar $60 \mathrm{~cm}$, konon penjaganya adalah seekor kuda.

3. Babaang Sele atau pintu selatan,berbatasan dengan teluk babaere, dengan tinggi 100 $\mathrm{cm}$ dan lebar $60 \mathrm{~cm}$,konon pintu ini dijaga oleh seekor kura-kura dan seekor kerbau.

4. Babaang Manrusu atau pintu rahasia, berbatasan dengan gua yang selanjutnya menuju teluk turungang,berukuran tinggi $160 \mathrm{~cm}$ dan lebar $60 \mathrm{~cm}$.

Sejarah gantarang mulai ditulis sejak masuknya islam digantarang yaitu pada masa pemerintahan Pangali Patta Raja (A Ahmadin, 2016). Dalam naskah Lontara yang bertulis Serang (huruf arab dalam Bahasa makassar) menjelaskan tentang kedatangan Datuk Ri Bandang ke Gantarang untuk tujuan mengislamkan Raja Gantarang. Yang pernah memerintah di gantarang adalah :

1. Mappasori Krg.Raja (1520-1567)

2. Pangali Patta Raja (1567-7-1612)

3. Tambangang Daeng Manrongrong Sultan Muhammad Zakariah (1612-1649)

4. Baso Ugi Dg.Magassing Sultan Muhammad Saleh (1649-1678)

5. Labao Dg.Maninggali Sultan Abdul Hidayah Muhammad Assiddiq (16781705)

6. Daeng Paduni ( 1705-1730)

7. Caco Dg. Ma'ruppa (1730-1761)

8. Hatibu Dg. Manrongrong (1761-1796)

9. Lanurung Dg. Rimonsong (1796-1819)

10.Baso Ali Dg. Biraeng (1819-1834)

11.Paleha Daeng Karaeng (1834-1858)

12.Cakele Daeng Manguntungi (1858-1894)

Pada masa pemerintahan kolonial Belanda pusat pemerintahan Kerajaan Gantarang di pindahkan ke Bonea karena alasan aksesibilitas oleh pemerintah kolonial. 
Islamisasi Selayar yang berawal dari sebuah perkampungan bernama Gantarang Lalang Bata (di pantai Timur), berdasarkan catatan yang termaktub dalam lontara setempat, bahwa ajaran Islam dibawa oleh Datuk Ri Bandang (Arifandi, 2019). Salah seorang dari ketiga datuk (dua di antaranya adalah Datuk Ri Tiro dan Datuk Patimang) ini, sengaja diutus oleh penguasa (raja) Arab Saudi untuk mengislamkan Buton dan Selayar.Dalam lontara dijelaskan sebagai berikut "nakana 1 Datu Ri Bandang nisuroak ri karaeng ri Makkah siangang Khalifayya ri Makka akkana anraikko ri Butung siagangko I Datu Ri Tiro, I Datu Patimang. Lekbaki aklampa tojemmi anrai ri Butunga appaka sallang na nampa mange ri Silayarak"

Penggalan kalimat yang tercantum dalam lontara tersebut bermakna "berkata Datuk Ri Bandang saya diperintahkan oleh Raja atau khalifah di Mekkah untuk ke Buton bersama Datuk Ri Tiro dan Datuk Patimang. Maka berangkatlah ke Buton untuk mengisiamkannya selanjutnya ia ke Selayar" (terjemahan bebas oleh: Ahmadin)

Jika mengacu pada keterangan berdasarkan bunyi naskah lontarak tersebut, maka dapat diketahui bahwa masuknya Islam di Selayar dibawa oleh Datuk Ri Bandang setelah ia mengislamkan Buton terlebih dahulu (Mayani, MayMayani, 2019). Bahkan informasi ini sekaligus mengukuhkan bahwa dibandingkan dengan Selayar, Buton lebih awal menerima Islam. Terkait dengan saluran Islamisasi tersebut, rupanya proses pengislaman di Gantarang (periode awal) hampir dikatakan tidak menerapkan satu saluran pun kecuali Tasawuf yang metodenya sedikit mendekati. Hal ini dipahami mengingat bahwa pengislaman di tempat ini, yang menurut catatan sejarah dilakukan oleh Datuk Ri Bandang, bukanlah sebuah misi politik maupun kepentingan dagang. Bila bercermin pada situasi sosial zaman dimana Islam baru pertama kali akan beradaptasi dengan kultur Arab Jahiliyah, tampak Nabi
Muhammad SAW mengalami tantangan serius. Betapa tidak, ajaran Islam sebagai doktrin baru harus bergesekan dengan kultur Arab Qurais yang menolaknya. Fanatisme kental terhadap nilai-nilai kultural yang mengkultus-sakralkan berhala-berhala, rupanya harus menjadi kendala awal terhadap pengembangan Islam yang hendak menghapuskan gaya hidup jahiliah tersebut.

Berbeda dengan proses pengislaman beberapa kerajaan besar di Sulawesi Selatan seperti Soppeng, Bone, dan Wajo yang menerima agama Islam melalui proses penaklukan (peperangan), di Gantarang justru kondisinya lain (secara damai). Hal ini tentu terkait dengan beberapa prakondisi, seperti sistem kepercayaan, psiko-sosial, maupun proses pengislaman yang kepentingan politik. steril dari Dua prakondisi pertama, berkaitan dengan alam pikiran dan karakteristik orang Selayar yang memiliki kepercayaan animisme dan dinamisme. Sebut saja di berbagai tempat baik di darat maupun di laut (termasuk sungai) dianggap memiliki penjaga, sehingga setiap orang memerlukan pengetahuan untuk menangkal atas gangguan makhluk tersebut. Tentang konsep animisme yang mengandung arti kepercayaan tentang realitas jiwa, dapat dilihat pada "animism: Encyclopedia Britanica" (Preece, ed., 1965).

Sekadar digambarkan bahwa setelah orang Selayar menerima ajaran Islam, Surat Al-Ikhlas kemudian dijadikan sebagai alat untuk mengusir setan (jin). Ilmu kesaktian jenis ini dalam bahasa setempat, disebut Pabbongka Setang (pengusir setan). Demikian pula surah lainnya dalam Al-qur'an, lalu dijadikan sebagai pa'rinring (melindungi diri dari kejahatan gbaib), pattahara (mengobati dengan mantra), dan sebagainya.

Tentang "Haji Gantarang" dan Berkah Tanadoang.Sulit menelusuri sejak kapan mulai lahir tradisi atau lebih tepat dikatakan istilah "Haji Gantarang", siapa yang memulai, dan untuk apa orang melakukan. 
Namun yang pasti bahwa hal ini tidak hanya dipahami sebatas istilah, sebaliknya diyakini (dipercayai) sebagai sistem keagamaan (Rezki Indriyani Mahmud, 2018). Demikian kentalnya kepercayaan orang-orang tertentu pada kesakralan tempat ini, sehingga seolah batas demarkasi antara ajaran Islam yang murni dengan bid'ah seolah sudah samar-samar.Menurut kepercayaan orangorang yang menyakini tradisi ini, bahwa menunaikan sholat Idul Adha selama 7 (tujuh) kali di Gantarang Lalang Bata, sama artinya atau kedudukannya dengan orang yang melakukan ibadah haji ke Tanah Suci Mekkah. Asumsi yang entah dalil apa yang dijadikan dasar ini, terbukti melalui kecenderungan banyak orang yang berasal dari luar Gantarang melakukan sholat Idul Adha di tempat ini. Bahkan sehari sebelum hari raya, mereka sudah berangkat dan menginap di rumah-rumah penduduk Gantarang. barakka (berkah), itulah salah satu bahkan inti motivasi mereka sehingga demikian antusiasnya mengunjungi tempat penting ini. Jadi ibarat Tanah Suci Mekkah di Arab Saudi yang mereka sebut Tanah

Parallua", Gantarang Lalang Bata pun dipercayai sebagai Tanah Parallu" (tanah yang penting). Bahkan tempat ini pun tidak jarang dinamakan sebagai miniatur Mekkah yang dalam bahasa setempat disebut Makka keke (Mekkah Kecil). Demikian pentingnya tempat ini, sehingga menurut sumber lisan dari mereka yang biasa ke tempat ini, bahwa orang-orang dulu berangkat ke Gantarang bukan hanya orang tua, tetapi beberapa di antaranya membawa keluarga yakni istri dan anak-anaknya.Kemudian tentang para pengunjung ke tempat ini, rupanya tidak hanya terdiri atas orang-orang Selayar sendiri. Sebaliknya, dari daerah lain juga kadang menyisakan waktu untuk melakukan kunjungan ke Gantarang. Sebuah cerita juga menjelaskan tentang adanya salah seorang yang berasal dari Tanah Bugis (tidak jelas Bugis mana), bahwa sekembalinya dari
Mekkah menunaikan ibadah haji, ia menyempatkan diri untuk ke Gantarang. Hal ini dimaksudkan sebagai upaya menyempurnakan ibadah haji yang telah ditunaikannya. Bahkan alasannya diperkuat oleh pengakuan bahwa ia memperoleh petunjuk atau ilham agar ke tempat ini.

Memperhatikan kecenderungan orang orang mengunjungi Gantarang, maka secara umum ada dua motivasi yakni untuk menunaikan sholat idul adha dan melepas nazar atau meminta berkah. Satu hal menarik dari fenomena "Haji Gantarang" ini, yakni mereka yang telah melaksanakan sholat di Gantarang tidak pernah ada yang menganggap dirinya maupun orang lain adalah haji. Selain itu, baik nama-nama tempat yang terdapat dalam embaya maupun istilah yang berhubungan dengan ibadah haji, tidak ditemukan di Gantarang. Dalam pengertian lain bahwa tidak ada rangkaian kegiatan selain sholat Idul Adha yang dilakukan seseorang, sebagaimana syarat dan rukun haji di tanah suci Mekkah. Dengan demikian, dapat disimpulkan bahwa keyakinan mereka terhadap kedudukan Gantarang sebagai "tanah suci" tak lebih sebagai tindak pengsakralan terhadap tempat tertentu yang dianggap tempat baik. Adapun anggapan 7 (tujuh) kali sholat di tempat ini sama kedudukannya dengan sekali ke Mekkah, mungkin awalnya hanya sebagai motivasi yang kemudian dimaknakan secara berlebihan.

\section{Kesimpulan}

Berdasarkan keterangan lontarak, bahwa Gantarang yang termasuk dalam wilayah 7araka7trative Selayar adalah gerbang masuknya Islam pertama di jazirah Sulawesi Selatan. Kedua, sebanyak 7 (tujuh) kali seseorang menunaikan sholat Idul Adha di Gantarang menurut para penganut kepercayaan ini, samna statusnya dengan berhaji ke Tanah Suci Mekkah di Arab Saudi. Ketiga, pemitos-sakralan yang berlebihan 
terhadap pusat Islamisasi ini, kemudian melahirkan kepercayaan bahwa di Gantarang ada bekas telapak kaki Nabi Muhammad.Sebaliknya, kepercayaan yang cenderung bercampur dengan alam mitologi ini, dimaknai secara kontektual. Sebut saja kepercayaan banyak orang tentang berhaji ke Gantarang, bukan tidak mungkin awalnya hanya merupakan sebuah kebiasaan orangorang di luar Gantarang terutama masa perkembangan awal Islam untuk menunaikan sholat sekaligus belajar agama Islam di tempat ini dan kemudian dianggap atau disejajarkan kedudukannya dengan belajar ke tanah suci Mekkah di Arab Saudi. Kepercayaan terhadap berkah yang dimiliki oleh Selayar, antara lain dapat diketahui melalui kencenderungan orang mengakhiri bacaan manteranya dengan kalimat "7araka doang". Bahkan kebiasaan ini masih tampak setelah Islam masuk ke Selayar, sehingga akhir mantera berbunyi: "7araka doang, 7araka la ilaha illallah, kunpayakun".

\section{BIBLIOGRAFI}

Ahmadin, A. (2008). Tanah Suci Gantarang: Berhaji Selain Mekkah. Lensa Budaya, 3(2), Agustus. Google Scholar

Ahmadin, A. (2016). Nusa Selayar: Sejarah Dan Kebudayaan Masyarakat Di Kawasan Timur Nusantara (Vol. 1). Rayhan Intermedia. Google Scholar

Ahmadin, Ahmadin. (2011). Misteri Jejak Kehadiran Nabi Muhammad di Tanah Gantarang: Jejak Siar Islam di Pulau Selayar. Rayhan Intermedia. Google
Scholar

Arifandi, M. (2019). Konsep Ajaran Aliran Muhdi Akbar di Kecamatan Bontosikuyu Kabupaten Kepulauan Selayar. Universitas Islam Negeri Alauddin Makassar. Google Scholar

Mayani, MayMayani, M. (2019). Perkembangan Hukum Islam Di Indonesia Pada Masa Kerajaan Islam Sampai Dengan Masa Reformasi. Jurnal Publikasi, 1(1). Google Scholar

Pratiwi, A. I. (2016). Akuntansi Karapan Sapi pada Masyarakat Madura dengan Pendekatan Etnografi. Jurnal Ilmiah Bisnis Dan Ekonomi Asia, 10(1), 6-9. Google Scholar

Rezki Indriyani Mahmud. (2018). Makna Tradisi Pattabek Bagi Masyarakat Perkampungan Tua Gantarang Lalang Bata Sebagai Kawasan Sejarah Dan Jejak Islam Pertama Di Kecamatan Bontomanai Kabupaten Kepulauan Selayar (Pendekatan Semantik). Google Scholar

Widianingsih, I. (2021). Makam We Tenri Dio di Kepulauan Selayar (Studi Akulturasi Budaya Islam dan Budaya Lokal). Universitas Islam Negeri Alauddin Makassar. Google Scholar

Wijaya, H. (2018). Analisis Data Kualitatif Model Spradley (Etnografi). Google Scholar

Winarno, K. (2015). Memahami Etnografi Ala Spradley. Jurnal SMART (Studi Masyarakat, Religi, Dan Tradisi), 1(2). Google Scholar

\section{Copyright holder :}

Syakinah (2022).

First publication right :

Action Research Literate

This article is licensed under:

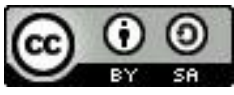

